\title{
The Relationship between Action Logics of Business Leaders and CSR Behaviours in the Ready Made Garment Sector of Bangladesh
}

\author{
Nika Salvetti", Andre Nijhof \\ Nyenrode Business Universiteit, Netherlands \\ Received December 18, 2019; Revised February 6, 2020; Accepted February 18, 2020
}

Copyright $\bigcirc 2020$ by authors, all rights reserved. Authors agree that this article remains permanently open access under the terms of the Creative Commons Attribution License 4.0 International License

\begin{abstract}
This study focuses on understanding the inner psychological (intrinsic) motivations that influence local business leaders in adopting CSR behaviours. The inner motivations are hereby considered as the mind-sets of individuals, the human capacity to interpret reality. According to the constructive developmental theories, individuals experience several stages of consciousness development, as a consequence of their deeper understanding of reality, wisdom and ego awareness. More specifically, building upon the Action Logics framework of Rooke and Torbert (2005), it can be considered what type of action logics relate to advanced forms of CSR behaviours. One of the main contributions of this study to the leadership and CSR literature is to describe each action logics as specific intrinsic motivation and clarify empirically the relationship between action logics of local business leaders and different stages of CSR behaviours, in a specific local context. An inductive research strategy is applied. Nine local business leaders participated in this research and triangulation was applied based on in-depth interviews, observations and company reports to determine CSR behaviours and how they are related to action logics. Template analysis was used for coding the findings. The study resulted in four distinctive patterns about the relationships between action logics and CSR behaviours. The study indicates that: (1) Higher action logics are needed to be engaged in more advanced stages of CSR practices; (2) It is at the achiever action logic level when leaders start moving towards advanced stages of CSR behaviours; (3) Lower action logics cannot induce advanced stages of CSR behaviours; (4) Business leaders with higher action logics can still apply practices of the full range of CSR stages. Based on these findings this paper provides recommendations for future research and managerial practice.
\end{abstract}

Keywords CSR, Action logics, Garment Sector, Bangladesh

\section{Introduction}

The interest in Corporate Social Responsibility (CSR) as a field of academic study is evident, from both a broad management perspective (Aguinis \& Glavas, 2012; Frynas \& Yamahaki, 2016; Su, Peng, Tan \& Cheung, 2016; Zheng, Luo \& Maksimov, 2015; ) and from more an international business perspective, with special emphasis on developing countries (Amaeshi, Adegbite \& Rajwani, 2016; Jamali \& Karam, 2016; Jamali, Karam, Yin \& Soundararajan, 2017; Kolk, 2016; Pisani, Kourula, Kolk, \& Meijer, 2017;) . One specific topic in this body of knowledge about CSR - and one that is especially relevant for this study - is the variation among CSR behaviours between companies (Amaeshi, Adegbite \& Rajwani, 2016; Jamali, Karam, Yin \& Soundararajan, 2017; Kolk, 2016). Several stage models about CSR have yielded insight into the progress in CSR behaviours, including related requirements (Benn, Dunphy \& Perrott, 2011; Maon, Lindgreen \& Swaen, 2010; Visser, 2011; Zadek, 2004). These stage models assume that greater CSR impact emerges from different styles of leadership. If we want to understand how CSR behaviours progress and advance, we cannot do so without understanding the action logics development of the leaders involved (Brown, 2014; Cook-Greuter, 2014; Nijhof \& Jeurissen, 2010; Spano, 2015; Stahl, \& de Luque, 2014). That is why this study seeks to focus on the individual level of analysis.

Moreover, the launch of the UN Sustainable Development Goals calls for collective efforts in the economic system to become more resilient in the face of crises and accidental and structural shocks, and to enhance the creation of value and the well-being and performance of all actors in society (Tideman \& Arts, 2013). Such a shift has a direct impact on business leaders who will have to 
change their business models: by focussing not only on financial returns but also by addressing societal demands for a more efficient and effective use of human and natural resources. For that a new form of leadership is required: leadership with better understanding of today's global challenges; leadership that looks beyond the simplistic and out dated economic worldview based on rational-economic behaviours focussed on short-termism and economic growth (Hamel \& Breen, 2007). Today there is an increasing attention towards responsible and conscious leadership (Akora, Elawar \& Cheng, 2019; Doh \& Quigley, 2014; Shafique \& Beh, 2017; Shi \& Ye, 2016; Stahl \& De Luque, 2014).

As stressed by Senge (2008) leadership is a key driver of sustainability if it is shaped by a new mind-set and abilities which are capable of guiding leaders to embrace the complexity that the sustainability challenge demands and to create value with multiple stakeholders. The focus on understanding the crucial role of business leaders in specific local context, in choosing for and implementing CSR initiatives has been neglected by empirical research (Maak \& Pless, 2006). Christensen, Mackey and Wetten (2014) argue that research on CSR has in the past mainly focussed on justifying the link between corporate social responsibility and corporate social performance; deeper understanding of the reasons for a company to engage in CSR - especially when the financial returns on investments are not so evident - has been marginally surfaced. According to the research of Aguinis and Glavas (2012) and more recently of Jamali and Karam (2016), only 4\% and 9\% of respectively reviewed articles on CSR focussed on individual level of anlaysis.

Angus-Leppan, Metcalf and Benn (2009) stressed the different interpretations of CSR might challenge the identification and validity of its behaviours. Thus, to better understand the complex relationship between leadership and CSR this study examines what intrinsic motivations influence local business leaders in a specific local context to adopt socially responsible corporate behaviours from the standpoint of their own interpretation.

For this it is best to embed the study in a context with a lot of dynamics surrounding CSR behaviours: the Ready-Made Garment sector (RMG-sector) in Bangladesh. The accidents of the Tazreen fashion factory (2012) and Rana Plaza (2013) have cast a long, dark shadow over the RMG sector of Bangladesh, despite its continuous export growth. Approximately 2000 workers died due to, among other factors, the negligence and irresponsible conduct of a variety of stakeholders in the supply chain, weak law enforcement of fire and building safety regulations, and finally, due to the inadequate compliance with CSR standards (BSR, 2013) ${ }^{1}$. It became evident that any failure to enforce social and environmental regulations exposes the sector to serious risk, undermining its growth. Consequently, in 2013 several

1 Business for Social Responsibility. Articles on Bangladesh. initiatives were launched to address the structural causes of the two deadly accidents by ensuring the implementation of health and safety measures on behalf of the garment workers. Since then, a number of irresponsible business behaviours and stakeholders have been identified in the supply chain, initiating the demand for change in the direction of higher levels of CSR (Grinter, 2013; US Department of Labour, 2013).

Remarkably and despite the international pressure and negative image this has generated for the products 'made in Bangladesh', there are some local business leaders whose decisions nevertheless embody more advanced stages of CSR. This makes the RMG sector in Bangladesh an interesting context to study variations in action logics and how they relate to progress in CSR, assuming that institutional factors alone will not transform the sector and make it more responsible and sustainable if a new culture and mentality in favour of CSR does not emerge (Shafique \& Beh, 2017; Stahl \& de Luque, 2014).

\section{Theoretical Justification of Action Logics Theory to Explain CSR Behaviours}

This study builds upon the leadership theory which focuses on the individual characteristics of leaders (traits, personality, skills, abilities, individual differences and charisma) (Christensen, et al., 2014; McCauley, Drath, Palus, O'Connor \& Baker 2006; Visser, 2011). Within this theoretical stream of inquiry, the Action Logics Development framework of Rooke and Torbert (2005) which applies the constructive development theory of Piaget (1954), then improved by Kegan (1980) and Loevinger (1976) to a managerial level - helps explaining how prominent the role of leadership is in the transition to more advanced stages of CSR.

With their action logics development framework, Rooke and Torbert (2005) identify seven stages through which an individual's reasoning and behaviour are progressively transformed, enabling the person to better understand and respond more effectively to complex circumstances and situations. The action logics perspective of Rooke and Torbert yields a more adequate understanding of how leaders 'interpret their surroundings and react when their power or safety is challenged' with respect to the precedent theories of Piaget, Kegan and Loevinger (2005: 67).

Following Rooke and Torbert's action logics development framework and its managerial implications, Basu and Palazzo (2008) emphasize the relationship between CSR and leadership styles. They argue, inter alia, that leadership has been the key driver of corporate ethics choices which contributed to overall company performance on CSR (Ciulla 1999; Hemingway \& Starkey, 2018; Paine, 1994; Shafique \& Beh, 2017; Stahl \& de Luque, 2014; Tourigny, Han, Baba \& Pan, 2019) Weaver, Trevino \& 
Cochran 1999). Leaders are seen as those who should set the ethical tone of the company to enable further CSR engagement (Trevino, Brown \& Hartman 2003; Tourigny, Han, Baba \& Pan, 2019).). Emphasis on the leaders' driving role in the promotion of CSR behaviours often results in idealization of those leaders, resulting in their recognition as charismatic leaders and champions of CSR (Boiral, Cayer \& Baron, 2008). More specifically, these leadership theories are founded on the assumption that leaders define organizational strategies partly based on their 'personal' traits, values, and idiosyncratic characteristics (Christensen et al., 2014).

Adding on this assumption, constructive developmental theorists (Brown, 2011; Cook-Greuter, 2014; Kegan 1994; Kohlberg 1969; Rooke \& Torbert 2005; Torbert \& Associates, 2004) assert that leaders with more mature action logics are more able to deal with today's complex challenges because they better understand the need to behave responsibly and ethically. These assumptions are grounded on the constructive developmental theories which expand on the early work of Piaget (1954), Kegan (1994) and Kohlberg (1969) on childhood and moral development to include the transformational processes and emotions related to the stages of adult development (McCauley et al., 2006). In particular the work of Torbert (1987) and Rooke and Torbert (2005), Cook-Greuter (1999. 2014) and Brown $(2011,2014)$ use the stages of development in leadership and management research to better understand how leaders think, act and make sense of the world's complexity. This because constructive-developmental theory suggests that leaders who demonstrate later stages of development might have the propensity of reaching greater levels of wisdom thus the ability to better understand and act on the complexity of today's world (Cook-Greuter, 2004, 2014; Spano, 2015). In fact, each meaning making stage of development is more complex than the previous one as it integrates, differentiates and includes a wider variety of experiences (McCauley et al., 2006).

According to the aspects of development mentioned in the constructive development theory, leaders are subject to the orders of development, organizing principles that determine the sense-making of individuals and influenced by the development movement, that inform how the regulative principles are formed and change over time (2006: 3).
Because of these principles leaders follow a development process that enables them to realize and reflect on the limitations of previous and current stages of sense making; thus helping them to realize a new order of experiences and realities that, according to the action logics theories, enable them to make sense of more complex situations and therefore be able to tackle more complex problems (Cook-Greuter, 2004, 2014).

In line with constructive-developmental theory, action logics can be defined as the patterns of thinking, systems of understanding and mind-sets which shape our capacity to understand the world and to react to its complexity. As explained by Brown (2011:2), it represents "the way that an individual organizes reality. It describes the developmental stage of meaning-making that informs and drives our reasoning and behaviour. It includes what we see as the purpose of life, what needs we act upon, what ends we move toward, our emotions and our experience of being in the world, and how we think about ourselves and the world". It is mainly influenced by how leaders read their surroundings and react to challenges when their power and safety are at risk, rather than their philosophy of leadership, personality or style of management (Kegan 1994; Rooke \& Torbert, 1998; Torbert et al., 2004; Cook-Greuter, 2004, 2014).

Based on Ego Development Theory, Cook-Greuter (2004, 2014) state that there are three dimensions to examine in relation to action logics: the Affective (how humans feel about things; what they are aware of and how they process their experiences); the Cognitive (how humans think; what they perceive as the logic behind their perspectives and how they make sense of experiences) and the Behavioural (how people interact; how they cope with situations and what they try to achieve). To gain a better understanding of the justifications which motivate CSR behaviours, it is useful to make a distinction between the action logics (explained by reference to affective and cognitive dimensions) and behaviour. This would help in depicting the relationship between motivation and action, which in turn would help explaining which action logics might be more suited to CSR behaviours, and what had motivated a certain CSR behaviour. The affective and cognitive dimensions are described in Table 1 following the interpretation of Cook-Greuter (2004, 2014), Rooke and Torbert (2005) and Brown $(2011,2014)$ as set forth below. 
Table 1. The Action Logics perspectives based on Cook-Greuter (2004, 2014), Rooke and Torbert (2005) and Brown (2011)

\begin{tabular}{|c|c|}
\hline Opportunist & $\begin{array}{l}\text { General characteristics: Self-defensive; focuses on immediate needs and opportunities; wins any way possible; } \\
\text { self-oriented; manipulative, believes that 'might makes right'; Cognitive style: Thinking is concrete and dichotomous } \\
\text { based on global, undifferentiated judgments and simple ideas: Things are black and white; Affective: life is hard; negative } \\
\text { mind. }\end{array}$ \\
\hline Diplomat & $\begin{array}{l}\text { General Characteristics: Conformist; focuses on social behaviours and expectations; avoids overt conflict; seeks to } \\
\text { belong; obeys group norms; rarely rocks the boat; Cognitive style: interested in the concrete and visible aspects of } \\
\text { experience; Affective: inner feelings are stereotypical and predictable and aligned to cultural expectations; they put great } \\
\text { value on appearance, status, material possessions, prestige and reputation. }\end{array}$ \\
\hline Expert & $\begin{array}{l}\text { General Characteristics: rules by logic and expertise; seeks rational efficiency; Cognitive style: Self-conscious; capable } \\
\text { of abstract thought and operations; these individuals internalize societal "shoulds and oughts"; Affective: they fear } \\
\text { incompleteness and vulnerability; don't want to lose their uniqueness and personhood. }\end{array}$ \\
\hline Achiever & $\begin{array}{l}\text { General characteristics: Conscientious; an achiever focuses on delivering results, effectiveness and being responsive to } \\
\text { society; Cognitive style: they think in terms of formal operations, and appreciate conceptual complexity; they are } \\
\text { concerned about consequences and priorities; they are aware of contingencies and perceptions of alternatives; they are } \\
\text { capable of revision and re-assessment leading to new goals; Affective: they feel guilty if they don't fulfil ideals and goals; } \\
\text { they fear loss of control and independence; heightened sense of responsibility. }\end{array}$ \\
\hline Individualist & $\begin{array}{l}\text { General characteristics: characterized by mental complexity and self-differentiation; such people are relativists and } \\
\text { promoters of creative ideas and differences in others; Cognitive style: Individualist; their focus is on the self in } \\
\text { relationship to systems and in interaction with systems; they abandon purely rational analysis in favour of a more holistic, } \\
\text { organismic approach in which feelings and context are taken into account and the process becomes as intriguing as the } \\
\text { product or outcome; they dismantle conventional wisdom; to them everything is relative. Affective: they experience } \\
\text { internal struggle and despair about ever finding their true self; they empathize with others and tolerate a variety of ideas, } \\
\text { behaviours and reactions. }\end{array}$ \\
\hline Strategist & $\begin{array}{l}\text { General characteristics: Autonomous; characterized by self-development and self-actualization; Cognitive style: } \\
\text { Capacity to see and embrace some paradox and contradiction. Toleration of ambiguity. Broad scope of thought. Perception } \\
\text { of self as regulator of a self-system with interdependent parts within a larger context. Affective: behaviours become the } \\
\text { expression of one's moral principles; their fears are of failure to fulfil their potential and of neglecting their own principles } \\
\text { of justice, tolerance, etc. }\end{array}$ \\
\hline Alchemist & $\begin{array}{l}\text { General characteristics: constructive and ego aware; these people focus on the interplay between awareness, thoughts } \\
\text { and actions, transforming self and others; Cognitive style: construct-aware, they have greater access to and understanding } \\
\text { of intuition, feelings, dreams, states of mind and body. Their knowledge helps them to make sense of experiences and find } \\
\text { meaning in life. Affective: the experience anxiety when alone and are incapable of creating lasting meaning through the } \\
\text { rational enterprise; they fear not being understood by others. }\end{array}$ \\
\hline
\end{tabular}

The behavioural dimension is one of the three components of the psycho-logical system of individual. It is the operative component which examines how adult individuals see the purpose of life, what needs they act upon and what they are moving towards (Cook-Greuter, 2014). It reflects the behavioral posture an individual adopts, along with the commitment and consistency evident in activities that impact an individual's perceived relationships (Basu \& Palazzo, 2008). Consequently, leaders evolve and they move through a development process which ultimately results in a more consistent capacity to innovate and transform, which might enhance their CSR behaviours (Bandura, 1989).

Based on the above theoretical premises, Table 2 describes the behavioural postures process in the stages of CSR behaviours, highlighting the motivation on which specific CSR behaviours (actions) have been based and how such actions have been justified by a practical interpretation of reality (vision about CSR) and the relationship established with their environment (relations with stakeholders) as an antecedent or consequence of the action. This interpretation is inspired by the different ambitions levels of corporate sustainability of Marrewijk and Werre (2003) that consider the influence of value systems on the motivations to apply CSR.
Taking into account the constructive development approach to CSR, this study aims to address the research gap concerning the determinants of CSR by analyzing the action logics of business leaders that induce the implementation of policies embodying CSR at various stages. The study's context - Bangladesh - further contributes to an understanding of how the challenging conditions in the Ready-Made Garment sector there, effect the development of the action logics of local business leaders. Therefore, the research objectives for this study are to analyse what influences local business leaders in Bangladesh to act in a socially responsible way, despite the complexities and challenges of the global economy; and to identify the distinctive action logics of these leaders that make them prone to pursue a different variety, in breadth and intensity, of corporate socially responsible behaviours. Thus the research aims to discover and describe the intrinsic motivational factors which determine the action logics - and consequently the behaviours - of local business leaders; hence the intention is that the study is both exploratory and descriptive: Exploratory, to clarify how the problem is to be understood, as well as descriptive to provide more detailed knowledge about the profiles of the individual business leaders included in this study (Bernard \& Ryan, 2010). 
Table 2. The Behavioural perspective (Conative), with specific reference to the context of the RMG of Bangladesh

\begin{tabular}{|c|c|}
\hline Compliant & $\begin{array}{l}\text { "CSR is not relevant; CSR is merely a tool to manage perceptions about the corporation's reputation and a way of } \\
\text { keeping the license to operate; CSR is about compliance with the law to avoid repercussions". (Visions of CSR) } \\
\text { Actions: The corporation needs to only comply with the minimum national standards and regulations; } \\
\text { Relations with stakeholders: Engage with stakeholders if it is an externally-enforced mandatory obligation; }\end{array}$ \\
\hline Philanthropic & $\begin{array}{l}\text { "CSR is relevant if it is in accordance with the expectations of society; being compliant is socially accepted; CSR } \\
\text { is a way to establish a desired reputation, and obtain prestige and recognition; CSR is considered to be limited to } \\
\text { such actions as providing financial and material support in the form of charitable donations" } \\
\text { Actions: Follow what competitors do in terms of CSR (i.e. provide ambulance; provide childcare facilities for } \\
\text { employees; open a kindergarten; participate in CSR awards competitions;...); make charitable donations; } \\
\text { Stakeholder relations: concerned with soothing tensions within the company and with other stakeholders; }\end{array}$ \\
\hline Efficient & $\begin{array}{l}\text { "CSR is a strategic tool to provide answers to technical problems; CSR is accepted if it can be shown to yield a } \\
\text { clear return on investment; Leaders pursue socially responsible corporate actions only if the given measures make } \\
\text { business sense." } \\
\text { Actions: Apply cost-saving approaches to CSR activities, i.e. Environmental treatment plants to reduce } \\
\text { environmental impacts (thus costs) and improve water efficiency; preference for proven technological approaches; } \\
\text { Stakeholders' relation: contribute to sharing technical knowledge and expertise on how to address socio-economic } \\
\text { and environmental challenges; active participation in thematic conferences and seminars; }\end{array}$ \\
\hline $\begin{array}{c}\text { Strategic-goals } \\
\text { oriented }\end{array}$ & $\begin{array}{l}\text { "The concept of CSR is received in all its complexity and broadly defined; CSR is integrated into company policy } \\
\text { and designed/accomplished by teams; CSR is seen as a tool to achieve complex goals in line with what the market } \\
\text { demands." } \\
\text { Actions: Start mainstreaming CSR within the organization; i.e. Set up CSR teams to deal with CSR issues at social } \\
\text { and environmental level; Stakeholders' relations: Oriented to engage employees in CSR management operations; } \\
\text { Lead managers in dealing with stakeholders; open to CSR information disclosure. }\end{array}$ \\
\hline Innovative & $\begin{array}{l}\text { "CSR is perceived as a way to achieve more, in order to move beyond the prevailing non-mandatory general } \\
\text { standards and norms of behaviour; CSR is a strategic tool which embraces the intuition, creativity and a range of } \\
\text { ideas from the people involved both inside the company and external beneficiaries. CSR is the individual drive of } \\
\text { the leader/manager and then becomes an internal aspect of the company DNA." } \\
\text { Actions: pursues innovative actions such as addressing poverty while helping employees to improve their living } \\
\text { conditions by contributing to food, health and educational costs; or by addressing contamination of water through } \\
\text { Environmental Treatment Plants but also in support of water purification mechanisms at the community level; } \\
\text { Stakeholders' relations: inclined to develop participatory approaches to involve employees; active consideration of } \\
\text { ideas and suggestions of other stakeholders; participation in global conferences and international involvement in an } \\
\text { advisory role on issues related to the 'common good'; }\end{array}$ \\
\hline Engaging & $\begin{array}{l}\text { "CSR is seen as a strategic tool to promote new ideas and approaches in order to better the world. CSR is a tool } \\
\text { for personal and organizational transformation. Charismatic leaders who want to make a difference actively take } \\
\text { social responsibility for corporate decisions." } \\
\text { Actions: Supporting the Government in designing and implementing new initiatives: i.e. health insurance systems for } \\
\text { the workers and overall population; partnering with other organizations such as the ILO to introduce decent work } \\
\text { programmes or with IFC with the PACT programme to address water contamination in the area where the company } \\
\text { operates; pursuing smart and innovative initiatives, which are not done by others; } \\
\text { Stakeholders' relations: active engagement of stakeholders to set up partnerships and cooperation to embrace efforts } \\
\text { and develop resources to address common socio-economic and environmental challenges; active participation in } \\
\text { governmental and industrial meetings contributing to the enhancement and transformation of the RMG sector; }\end{array}$ \\
\hline Transformative & $\begin{array}{l}\text { "CSR is the way to improve the world by transforming it; Leaders are catalysts and transformers; CSR reaches } \\
\text { the level of stewardship and inspiration for others to follow." } \\
\text { Actions: conceiving and applying new business strategies and models to integrate CSR within the company and to } \\
\text { contribute to the welfare of society. } \\
\text { Stakeholders' relations: inspirational drive to engage other stakeholders in implementing CSR in order to contribute } \\
\text { to the transformation of the overall industrial sector; active involvement in various organizations and events to } \\
\text { promote societal prosperity and support humanitarian global causes; }\end{array}$ \\
\hline
\end{tabular}




\section{Methodology}

Based on the previous section the research problem can be set forth as follows: especially in a context like Bangladesh, local business leaders are the key actors responsible for taking decisions that impact society, the economy and the environment. Hence they are the ones whose conduct can influence and promote sustainable development. However, only those leaders who have developed more mature action logics tend to behave in a more socially and ethically responsible manner (Akora, Elawar \& Cheng, 2019).Carey, Patsalos-Fox \& Useem, 2009; Boiral et al., 2009; Brown, 2011, 2014; Woszczyna, Dacko-Pikiewicz \& Lis, 2015).

\subsection{Research Strategy}

The research takes an interpretative interactionism perspective as the author lived and worked in Bangladesh from 2011 to 2014, witnessing the daily interconnection with the phenomenon and its participants (Denzin, 2001). This enabled the author to more accurately interpret the feelings, emotions and experiences of the business leaders who practice CSR, helping her to take the specific institutional context and its historical momentum into account.

\subsection{Sample Design}

The unit of analysis is local business leaders operating in the garment sector of Bangladesh. A non-probability, purposive sampling of such leaders has been taken. In a context that emphasizes compliance with standards in relation to CSR this study can only reach its objectives if it focuses on the front running business leaders in the
Ready-Made Garment Industry in Bangladesh. Front running refers to the more developed stages of CSR behaviours especially Innovative, Engaging and Transformative behaviours - as described in Table 2. The selection criteria for the leaders was based on their origin/nationality (local), their CSR orientation and status as recognized leaders (of "socially responsible" businesses) and the ownership characteristics of the business they lead (locally-owned businesses). A detailed profile of the chosen local business leaders is provided in Table 3 .

A number of steps were followed in obtaining the sample of the (CSR) business leaders in order to reduce bias and any margin of error. In order to get an encompassing overview of the recognized leaders of socially responsible businesses, an initial list of fifteen potential business leaders was drawn. This initial list was based on including all leaders listed in specialized business reports or of those who won a CSR/Sustainability award. This initial list was reviewed by the author while attending CSR award conferences, professional meetings and by interviewing experts, chosen through snowball sampling technique. After inviting all identified leaders - fifteen in total - to participate in the research process, a pre-test of CSR was distributed on line to validate their level of interest, knowledge and commitment on the topic. Upon completion of this identification process, nine leaders agreed to undergo the full interview process. The relatively small number of cases is justified and explained by the rationale of purposive sampling; and, the fact that these cases represent, according to the screening with experts, the majority of the business leaders at the forefront of CSR practices in the Ready-Made Garment industry in Bangladesh.

Table 3. Characteristics of the leaders interviewed

\begin{tabular}{|c|c|c|l|c|c|c|}
\hline $\begin{array}{c}\text { Interviewee } \\
\text { code }\end{array}$ & \multicolumn{1}{|c|}{ Position } & Company nature & Nationality & Gender & $\begin{array}{c}\text { Education } \\
\text { Background }\end{array}$ & Religion \\
\hline I1 & Managing Director/Co-Owner & $\begin{array}{c}\text { Family owned } \\
\text { company }\end{array}$ & Bangladeshi & M & Engineer (Eng.) & Muslim \\
\hline I2 & $\begin{array}{c}\text { Chairman/Managing } \\
\text { Director/Owner }\end{array}$ & $\begin{array}{c}\text { Family owned } \\
\text { company }\end{array}$ & Bangladeshi & M & Eng. & Muslim \\
\hline I3 & Managing Director/Owner & $\begin{array}{c}\text { Family owned } \\
\text { company }\end{array}$ & Bangladeshi & M & Eng. & Christian \\
\hline I4 & Director & $\begin{array}{c}\text { Family owned } \\
\text { company }\end{array}$ & Bangladeshi & M & Technical & Muslim \\
\hline I5 & Managing Director & $\begin{array}{c}\text { Social Business } \\
\text { Owner) }\end{array}$ & Bangladeshi & M & Eng. & Muslim \\
\hline I6 & $\begin{array}{c}\text { Managing Director (wife of } \\
\text { company }\end{array}$ & Bangladeshi & F & Phd & Muslim \\
\hline I7 & $\begin{array}{c}\text { Managing Director/main } \\
\text { shareholder }\end{array}$ & Public holding & Bangladeshi & M & Phd & Muslim \\
\hline I8 & Chairman/main shareholder & Public holding & Bangladeshi & M & Eng. & Christian \\
\hline I9 & $\begin{array}{c}\text { Chairman/ Managing } \\
\text { Director/Owner }\end{array}$ & $\begin{array}{c}\text { Family owned } \\
\text { company }\end{array}$ & Bangladeshi & M & Eng. & Muslim \\
\hline
\end{tabular}

Source: The Author. Data were retrieved from face-to-face interviews; sustainability reports and website information. 


\subsection{Data Collection}

To strengthen the validity, the method triangulation of Denzin (1978) has been applied. This method checks the validity of an interpretation based on a single source of data against data derived from other sources as well as from informants (Hammersley, 2008). This provided a deeper understanding of the phenomena, which is reflected in the main objective of this study.

A first method to collect qualitative data was done with a pre-test CSR instrument. This instrument was designed with both open-ended questions and priority ranking measurements. The pre-test had the objective to gather general information on the perceptions of selected business leaders on the meaning and significance of CSR, its application and the general personal motivations in applying CSR.

A second step in the data collection process was based on Company visits. The author observed conditions on site of the nine selected companies to validate the interpretations elaborated in the pre-test of CSR, by visiting each of the garment factories owned and managed by the business leader. This allowed the author to observe and gain a greater depth of understanding of the physical conditions in which each factory operates and allowed for additional conversations to corroborate to some extent whether the results of the pre-test were consistent with the actual practice.

The third and final step is based on in-depth interviews with the nine business leaders. The interviews were scheduled in two sessions. Each interview took place in the headquarters of the company. The first addressed the 'intrinsic motivations' of leader and was carried out in approximately 2 hours. The second addressed the 'extrinsic motivations' for an approximate 3 hours in depth interview. The interview protocol, shown in the appendix, was structured to include open-ended questions in order to obtain qualitative input. The interviewees did not give consent to tape record the interviews and gave preference to anonymity. The content of the interviews had been written in the author personal notebook and duly transcribed in individual word documents.

\subsection{Data Analysis}

All interviews were analyzed with an inductive analytical procedure called template analysis (Lee \& Lings, 2011; King, 2004). The a priori template utilized at the start of the coding process is the combination of Table 1 (Action Logics) and Table 2 (Behavioural Perspective).

Based on the definitions mentioned in these tables, key words were identified as guidelines for the coding process. The use of template analysis, including its iterative procedure of revision and readjustment, is justified: the intent of this study is to strengthen extant theories. Extant theories have, thus far, not been adequate to explain the phenomena under study and to provide satisfactory and comprehensive answers to the research questions
(Christensen et al., 2014). In fact the assumption behind the Action Logics development theory (as applied to understand corporate conduct) is that those leaders who have developed more mature action logics will be able to expand and enrich their CSR practices (Brown, 2011).

With template analysis, in-depth interview transcripts and all other relevant textual data are thematically analyzed following a coding process that helps with the formulation of descriptive, interpretative and overarching themes. The descriptive themes are coded using the a priori reference coding template. For example the next quote of Informant \#1 was code as an indication of Diplomatic Action Logic: " And in this example the Diplomatic Action Logic was linked to Philantropic behaviour based on the next quotes mentioned in the same context of the interview as the Diplomat Action Logic: "Yes we do apply CSR. We apply CSR in a variety of ways such as donations, service providing, educational support, and so on." and "That is why we built better roads, living conditions, provided an ambulance to be used by workers and local villagers, ATM booth, influence on local government to provide the requested needs. The amazing benefit is that local communities respect and admire our company, so much that during the last hartals and political unrests, no one car of our company was attacked."

Once the descriptive themes are all identified and coded, the second level of coding looks for Interpretative themes (King, 2004). The interpretative themes are built on the interpretation of the descriptive themes to highlight the relationship between the two variables, the action logics and CSR behaviour. The relationship is conceptualized based on the interpretation of the corresponding action logics in relation to the CSR behavioural dimensions. In this example, the Diplomat is someone who is responding to what others are expecting from him/her, as he is in a stage of ego development which avoids confrontations. This action logic drives him/her to react and act upon it in a way that he recognizes the need to apply CSR (CSR Vision), but limiting it to donations and charitable actions (philanthropic approach) in order to satisfy the expectations of society to prevent any negative reactions (Stakeholders' relationships).

Based on a clustering of interpretative themes, the overarching themes were disclosed. In total four overarching themes emerged from the data, each representing a pattern in the identified relationships between action logics and CSR behaviours. More detailed explanation of the four overarching themes is provided in section four.

\section{Findings \& Discussion}

The main findings reveal that local business leaders do follow different action logics. According to constructive development theories (Cook-Greuter, 2014; Loevinger, 1976; Rooke \& Torbert, 2005) this is a normal pattern, as later stages of action logics can only be reached by moving through previous and less mature action logics. Once a specific level of action logic has been achieved, it does not 
disappear but feeds the individual's sense-making process even when he adopts more complex or mature action logics; this is because each later action logic includes and goes beyond the previous one. Thus current action logic is the result of the experiences and knowledge a person has previously accumulated.

The Table 4 shows the number of quotes identified per action logic. The frequency of quotes, shown in tallies, cannot determine the dominant action logic; however it initially yields some interesting patterns of sense-making, in that all respondents are able to reason at the level of Individualist and Strategist, some even at the level of Alchemist. However this doesn't mean that the other action logics become irrelevant. In fact looking at the Achiever action logic, it yields the highest frequency of quotes per respondent. Reading the table vertically, it can also be observed that each leader has no dominant action logics but can still express several action logics at the same time. This implies that other stages remain relevant, depending on the contextual circumstances Moreover it is expected that more mature/advanced action logics would enable a leader to interpret the complexity of reality in a way that would nurture several and advanced forms of CSR behaviours.

To establish what type of action logic gives rise to a different level of CSR behavior, the first coding process helped in identifying the action logics of each leader and the relevant level of social responsibility evidenced by the business in its dealings (descriptive themes). This could then be used to establish the relationship between each action logic and CSR behavior (interpretative themes). The study resulted in 55 identified relationships between action logics and CSR behaviours. The overview of the relationships is shown in Table 5 and the overview of the interpretation of this relationship is shown in the remainder of this section (the six overarching themes). The grey shadows in Table 5 highlight the different level of frequency, being the lightest the least and the darkest, the highest. Reading the findings horizontally, it shows which action logic is stated in the interview to relate with which CSR behaviour; while vertically it puts emphasis on the CSR behaviours and the reasoning and justification behind their applications. For example, in table 5 it can be appreciated that beyond the Achiever level, leaders are more prone to adopt advanced forms of CSR behaviours. All the identified relationships were further clustered in four distinctive patterns, producing overarching themes, as shown at the end of Table 5. Each of these four themes will be explained next.

Table 4. Preliminary patterns in action logics for the Informants

\begin{tabular}{|c|c|c|c|c|c|c|c|c|c|}
\hline Action Logics & I1 & I2 & I3 & I4 & I5 & I6 & I7 & I8 & I9 \\
\hline Opportunist & & & & I & & I & & & \\
\hline Diplomat & III & I & I & II & I & & I & I & I \\
\hline Expert & II & I & & & II & & I & II & I \\
\hline Achiever & IIII & IIII & IIIII & IIIII & IIII & III & I & III & II \\
\hline Individualist & I & III & IIIII & III & III & II & I & I & I \\
\hline Strategist & II & II & II & I & II & II & II & III & \\
\hline Alchemist & IIIII & & & & I & & II & & \\
\hline
\end{tabular}

Table 5. Overview of relationship between action logics and CSR behaviours

\begin{tabular}{|c|c|c|c|c|c|c|c|}
\hline $\begin{array}{l}\text { CSR Behaviours } \\
\text { Action Logics }\end{array}$ & Compliant & Philanthropic & Efficient & Strategic & Innovative & Engaging & Transformative \\
\hline \multicolumn{8}{|l|}{ Opportunist } \\
\hline \multicolumn{8}{|l|}{ Diplomat } \\
\hline \multicolumn{8}{|l|}{ Expert } \\
\hline \multicolumn{8}{|l|}{ Achiever } \\
\hline \multicolumn{8}{|l|}{ Individualist } \\
\hline \multicolumn{8}{|l|}{ Strategist } \\
\hline \multicolumn{8}{|l|}{ Alchemist } \\
\hline Theme 1 & \multicolumn{7}{|c|}{$\begin{array}{l}\text { 1. More mature action logics are needed to drive the development of more advanced stages of CSR } \\
\text { practice }\end{array}$} \\
\hline Theme 2 & \multicolumn{7}{|c|}{$\begin{array}{l}\text { 2. It is at the Achiever level of action logic that leaders start moving towards advanced stages of CSR } \\
\text { behavior }\end{array}$} \\
\hline Theme 3 & \multicolumn{7}{|c|}{ 3. Less mature action logics can not induce advanced stages of CSR behavior } \\
\hline Theme 4 & \multicolumn{7}{|c|}{$\begin{array}{l}\text { 4. Business leaders with more highly-developed action logics can still apply practices of the full range of } \\
\text { CSR stages }\end{array}$} \\
\hline
\end{tabular}




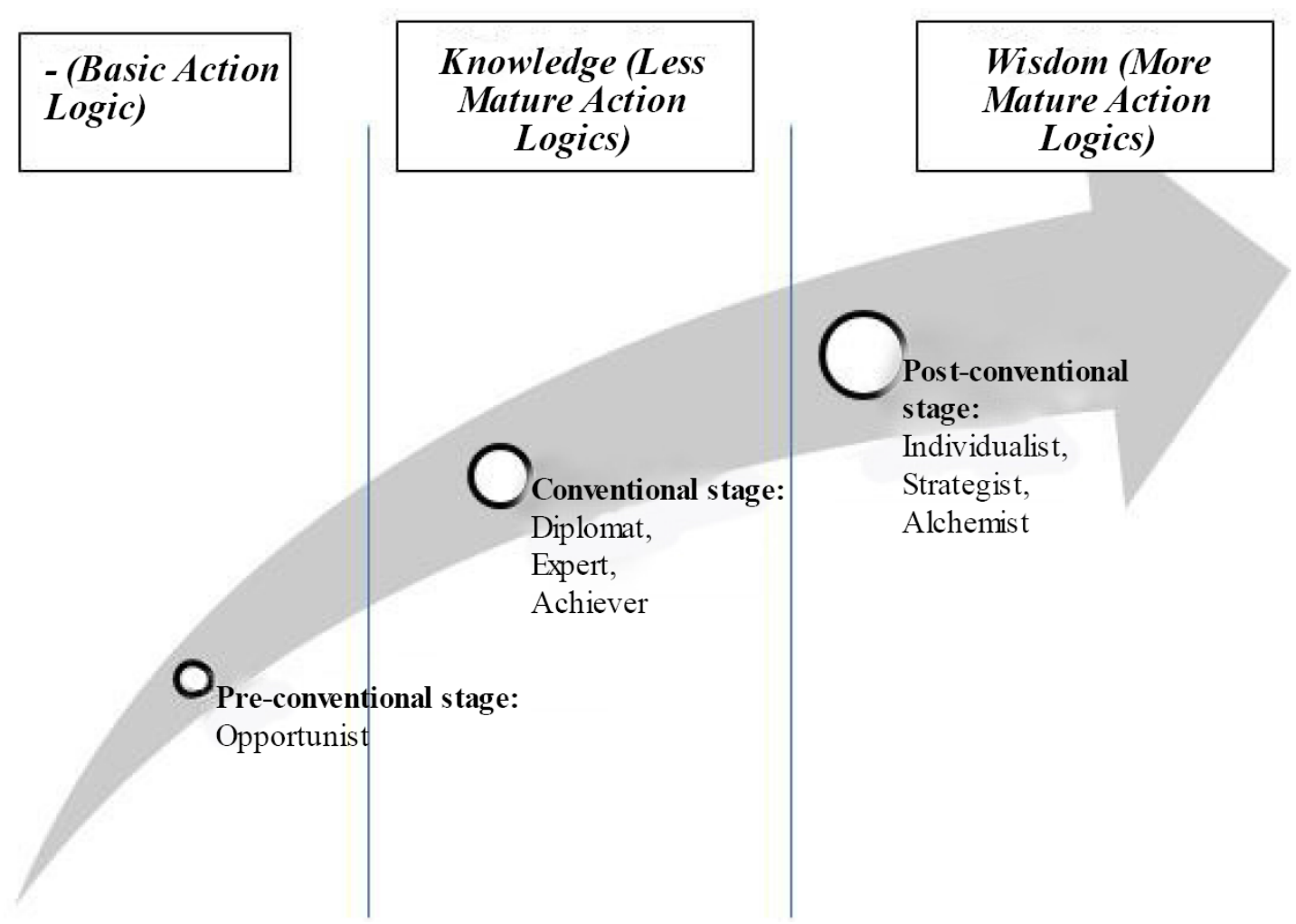

Figure 1. Progression of action logics (The Author with reference to Cook-Greuter, 2004)

(1) More advanced/mature action logics are needed before companies are engaging in more advanced levels of CSR (Theme 1);

The relationship between action logics and CSR behaviours are explained by the Ego Development Theory (Cook-Greuter, 2004. 2014), that describes how adults' development can be understood within a 'psycho-logical system' built on the interrelation between the operative, affective and cognitive components. Thus each stage of adult development is the synthesis of doing, being and thinking. 'Human development in general can be looked at as a progression of different ways of making sense of reality or different stages' (2005:3). In the Figure 1, the different stages of action logics, can be shown as progressing from a pre-conventional reasoning stage to a conventional linear reasoning till attaining a post-conventional understanding stage. Thus, to pursue more complex sustainability initiatives, leaders need to develop more advanced/mature action logics which enable them to easily understand the complexity and dynamism of the world (Boiral et al., 2008; Brown, 2011, 2014; Spano, 2015; Torbert et al., 2004; Woszczyna, Dacko-Pikiewicz \& Lis, 2015).

The research findings initially support these statements: they reveal that at the prevailing action logics of the Individualist, Strategist and Alchemist CSR behaviors correspond to those belonging to strategic, goal-oriented and innovative behaviors that lead to engagement and transformation. The three most mature action logics correspond to the post-conventional ego development model of Wilber according to which leaders gain a system view of the world and wisdom (Wilber, 2000). Moreover looking at it from the standpoint of constructive development theory, the same reality is interpreted by multiple representations which focus on different areas of interest and interrelationships (Cook-Greuter, 2014).

The findings show that with the action logic of the Individualist a leader tends to exhibit strategic and innovative behaviour, and in exceptional cases, reaches the transformative stage. The Individualist has a considerably deeper understanding of reality compared to less mature action logics and such leaders are able to appreciate the overall dynamic system. Their belief system is in the range between the independent and interdependent stage, in which the belief systems of others (society) interconnect with their own. As such an Individualist experiences mental complexity and self-differentiation, they tend to promote and internalize ideas which vary from those prevailing in other companies. For instance "I 3 " is the only leader, among the nine identified, that has set up a CSR team whose manager is participating in all of the most relevant decision making processes.

"I feel I am engaging my staff in applying CSR. I have a team on CSR" (I3).

But it is at the innovative stage that the Individualist applies most of the practices pertaining to CSR. At this behavioural stage, the individualist leader perceives CSR as a way to do more and move beyond general standards and norms of behaviours. This is the stage at which a corporation 
pursues socially responsible practices involving sustainable solutions to solve problems which directly and indirectly affect the company.

"Most of workers are female coming from villages and they are not aware of their health; they can not afford sanitary pads so we decided to produce sanitary towels/pads based on the technology developed in India" (I4).

The transformative stage is reached when the self-differentiation of the Individualist motivates such a leader to adopt actions in cooperation with others - actions that have the potential to transform the industry.

"Now we have new business partners which demand other requirements. We adjust to the new market, marketing, ensuring the compliance recommendations; revitalizing ourselves: changing from style with large quantity; to multiple styles with smaller quantity” (I7).

The Strategist is one who has attained a stage of ego-development rich in wisdom, a place from which they can enjoy their autonomy by seeing their own beliefs become fully interdependent with the whole system. Such individuals have gained a wider capacity to enunciate and accept contradictions and ambiguity; they have broader scope in thought and belief. These people perceive their role as regulators of the system they created and whose decisions and actions are the expression of their beliefs and moral principles. They strive to deliver what is possible for the system operating at its highest potential and to act in accordance with their own moral principles.

According to the findings of this study, the strategist is able to pursue practices exemplifying various stages of CSR behaviour, yet such individuals mainly focus on the Innovative and Engaging stages. However, as argued by Torbert and others (Fisher \& Torbert, 1991; Rooke \& Torbert, 1998; Torbert \& Associates, 2004), the Strategist action logic is particularly decisive in leading to the transformation of any organization by changing the culture, practices and inherent norms and habits.

At the innovative stage, leaders seek to translate their moral principles and beliefs into practice by applying new business models or strategies. "I5" is one example of this, having been founded upon the philosophy of the social purpose.

"In 1997 I started having in mind the social purposes of labour intensity, social investment, jobs' creation to contribute to foreign currency"(I5)".

Interestingly, according to findings, it is only the Strategist who is able to apply CSR practices at the Engaging stage. This can be explained by the fact that the Strategist is an autonomous and charismatic leader who aims at self-actualization by embracing diversity and ambiguity. At this stage Strategists look for cooperation and partnerships to join efforts in addressing common challenges.

"We don't contribute to society because we are expecting something in return. Also partnering with other organizations, create alliances to address socio-economic and environmental problems" (I3).

For instance, "I3" actively engages with the local government to carry out environmental initiatives such as cleaning the city's lakes, but also promotes environmental awareness campaigns at local universities.

Finally, the Alchemist is a person who builds on the interplay between awareness, thoughts and actions. Such people have a deeper understanding of intuition, emotion and states of mind and body. They can make sense of various experiences and find meaning in life. They generate transformation by building their own 'ideal' organization or work alone doing what they believe is the best to contribute to humanity. Because of their highly-developed awareness and their intent to contribute to a better world, these people are in the position to adopt transformative behaviours and practices and to inspire others to follow. In the specific case of "I1", the managing director actively participates in national and international seminars, workshops and CSR events, to share his experience and inspire others to use sustainable business models. Recently he was invited by SIWI to the Swedish Water Week where he presented his company's technological approach to enhance water management efficiency.

"I practice CSR and they consider me as an inspirational leader in the industry. In seminars, workshops and CSR events, I focused as an inspiring story by other attendees" (I1).

(2) It is at the Achiever level of action logics that leaders start moving towards more advanced/mature CSR behaviours (Theme 2);

From the ego-development perspective, the Achiever is one who continues to work with conventional linear reasoning and masters knowledge, in the sense that such individuals can think in terms of formal operations, appreciate complexity and understand causal relationships; they are able to predict, measure and explain. They start relying on their own belief system, thus becoming more independent in relation to decision-making processes. From the action logic perspective, this implies they are able to appreciate conceptual complexity; From the standpoint of how this corresponds to the various stages of CSR behaviour, the Achiever is one who behaves efficiently, seeing CSR as a strategic tool to provide answers to technical problems and save costs.

At this stage leaders would not venture on to pursue more advanced forms of CSR if there is no evident prospect of a potential return on investment.

"At the end helping workers with the improvement of their eyesight, it is a very low cost investment with high returns because of increased safety and productivity of the worker" (I2);

But as the Achiever considers formal operations, delivery 
of results and remains concerned about consequences and priorities, they start to be aware of contingencies and perceptions of alternatives which lead them to adopt Strategic behaviour:

"Investing in Human resources help build up the trust of my employees, their motivations, loyalty to the company and their discipline. This contributes to labour productivity and efficiency" (I3);

In affective terms the Achiever feels guilty if they fail to deliver results and fulfil their ideals; they fear loss of independence and control, and they experience a heightened sense of responsibility for their actions towards society. This may explain why the Achiever could even go beyond the strategic stage of CSR and adopt Innovative and Transformative behaviour when leaders become aware of the need to look beyond the company's boundaries and seek to take action, and make contributions, having greater impact on the wider society.

"Last year a documentary was shot with the New Zealand $T V$ in collaboration with BBC to experience the life of the workers in their jobs as well as in their houses, mainly shanty and slums" (I4);

With transformative behaviour, CSR reaches the level of stewardship and provides inspiration for others to follow as new business models and strategies are used by the company but potentially have a wider effect on the whole of society.

"Final achievement I got recognition from UNFCCC as the first CDM project for garment factory (2014). A Germany company accepted to place an order of $20 \mathrm{mln}$ pieces as a recognition of the CDM project" (I5);

(3) Less mature action logics can not induce more advanced stages of CSR behaviour (Theme 3);

Less mature action logics, Opportunist, Diplomat and Expert, correspond to the pre-conventional way of sense-making at the knowledge stage at which leaders are less effective at designing and applying strategies which lead to higher individual and corporate performance. This is the main result of the research conducted by Rooke and Torbert in cooperation with Cook-Greuter (2004). Their study also explained that the Opportunists, Diplomats and Experts are those who are less effective leaders due to: their inability to look beyond their own self-interest (Opportunist), their aversion to initiating change, their preference in favor of avoiding conflict (Diplomat) and their high opinion of their own expertise and knowledge, rendering them less willing to accept any other opinions (Expert).

Findings with regard to the action logic of the Opportunist reveal that such leaders do indeed comply with Government requirements and the requirements of buyers as a commitment made by the owner:

"Our main product is RMG. Compliance is a very common issue; but CSR is more than that. "B" I am fully compliant since the beginning; if a company is not totally compliant can not do more or paying attention to other issues of CSR, such as contributing to society” (I4).

At the Diplomat level, philanthropic behaviours are quite common, as they aim at ensuring the 'license to operate' in local communities thus avoiding negative social repercussions:

"Building better relationship with the community where they operate; retention and loyalty of staff; less security's costs" (I8);

Finally the Experts do apply their rational mind to achieve the planned targets. All CSR actions are taken as being functional, in terms of saving costs, thus enhancing efficiency and productivity.

"Engagement. Once you are engaged everything is running easier and the company will work better and more efficient. Engagement policy has reduced workers' turnover to $2.5 \%$. Lean process is followed to enhance productivity, reducing waste thus improve competitiveness" (I9));

(4) Business leaders with more mature action logics can still apply practices involving the full range of CSR stages (Theme 4);

From the findings it emerges that despite the Strategist action logics of certain leaders, they still practice philanthropic work. Following the constructive development propositions as formulated by McCauley et al. (2006), the findings suggest that leaders who have progressed through higher orders of development do not subsequently regress; instead their perspective reflects previous alternative ways of thinking and doing. And if moving from one level of conduct to another is driven by limitations, those limitations would include coming to understand what measures would be most beneficial and useful. The environment being increasing complex, advanced practices of CSR may be limited. From a legitimacy point of view, leaders dealing in a complex and ambiguous environment understand the importance of respecting local cultural values and norms. Accordingly they tend to respond to societal demands by aligning their actions to perceived expectations (Basu \& Palazzo, 2008). Furthermore, organizations usually tend to adapt and conform to what is the most common practice as a result of external stakeholders' pressures and uncertainty (DiMaggio \& Powell, 1983; Reimann, Rauer \& Kaufmann, 2015; Su, Peng, Tan \& Cheung, 2016; Zheng, Luo \& Maksimov, 2015).

Consequently, even though a leader may have reached the strategist stage in his/her action logics, that leader is still going to act as if he or she were at the Philanthropic stage - as a response to societal expectations - and to comply with rules and regulations of various stakeholders.

"Once we identify the needs of people, we are more effective in helping them out. Rather than choosing random activities, we get to select a program which would be of potential benefits to the community" (I1).

"Il" built better roads, improved living conditions, 
provided an ambulance to be used by workers and local villagers, set up an ATM booth, and influenced local government to provide the requested needs.

However as the strategist is also able to recognize the added value in terms of the financial and non-financial returns from CSR activities, such leaders can easily engage in more complex and sophisticated activities involving CSR which are not based upon mere financial return. Taking the example of I1, and connecting to his strategist action logic, he approaches the support to local communities with a variety of CSR practices. While responding at the philanthropic level, he set up the Matin Jinnat Foundation to provide basic support to all local communities surrounding the factory, repairing roads, building schools and health centers. At the efficiency level, he attended to the workers of his company and their families by equipping the medical centers of his company (within and outside the factory) with a wide range of tests. But it is at the engagement level that he conducts community surveys through company-operated welfare offices in cooperation with local NGOs. Such surveys identify specific needs, and action can be taken by ad hoc measures such as educational and vocational training in the public schools: Hatimara School and College and Kashimpur High School. In addition loans are available for startups and for SMEs to address local market demands.

Further research should include a more thorough examination of the extent to which the complexity of the surrounding institutional environment motivates the development of more advanced action logics.

\section{Conclusions and Recommendations}

The research had as its objectives to depict CSR determinants, in terms of the action logics which motivate local business leaders to adopt CSR behaviours despite the challenging context and on top of what is legally required. The research findings have revealed six main patterns which have implications regarding the application of advanced forms of CSR.

The first pattern confirms the constructive development theory by demonstrating that more mature action logics are needed to engage in more advanced forms of CSR. This also explains why, despite the challenging conditions of the business environment in Bangladesh, there are still local business leaders who preach and practice CSR at the Innovative, Engaging and Transformative stages. But it is only at the level of the action logic of the Achiever that leaders start moving towards advanced stages of CSR behaviour. However even with more mature action logics business leaders can still practice the full range of CSR activities. This is due to the fact that more advanced action logics enable a leader to have a wider understanding of reality based on previous stages of knowledge and consciousness, giving them the ability to expand the range and intensity of their company's socially responsible practices. That is why for example the Alchemist can still adopt philanthropic behaviours.

Nevertheless, less mature action logics can not induce more advanced forms and stages of socially responsible corporate behaviour. Those leaders who have a pre-conventional way of sense-making at the knowledge stage are less effective in, and capable of, designing and applying strategies which lead to higher individual and corporate performance.

All the above helps in connecting leadership theories - in this case constructive development theory - to CSR, thus contributing to a better understanding of the intrinsic motivations which induce socially responsible behaviours, in terms of the intensity and breadth of socially responsible corporate actions.

This study also gives rise to several managerial and academic recommendations. As mentioned in theme 3, this study indicates that less mature action logics can not advance CSR practices. Consequently managers would be well advised to design ad hoc leadership programmes in Bangladesh which would promote the development of leaders, encouraging leaders to adopt more mature forms of action logics. Such programmes should reconcile academic propositions with successful CSR practices which have been implemented in the RMG sector of Bangladesh as well as in other Asian countries. To achieve that, specific attention should be paid to the role of the local business leaders as catalysts: promoting socially responsible corporate practices and enunciating the ways that such practices benefit both the company's overall performance as well as society. Sharing their successful examples of business experiences in the local market as well as internationally could trigger an isomorphic chain of action supporting transformation of the sector and enabling operations within the industry to continue on a more sustainable basis.

To complement the above recommendations and taking into account the challenging environment of the RMG sector of Bangladesh, it is important to enhance the capacity of local research institutes to expand their research to identify and analyze the institutional factors that induce more advanced stages of CSR behaviour. Understanding the intrinsic and extrinsic factors that either enable or inhibit the development of more mature action logics might help in identifying the best strategies to promote the sustainable transformation of the sector.

A new research agenda is indeed required to stimulate the development of the RMG sector, broadening the focus to include stakeholders' management, change theory, institutional analysis, market transformation and leadership studies. In particular, a starting point would be to thoroughly examine the dependent variable of this study - the CSR behaviours - and test empirically which assumptions are correct under what conditions for each of the various stages of socially responsible corporate behaviour.

Finally it is necessary to recognize that linking leadership theory to CSR must also be considered in the context of 
institutional and/or stakeholder theory to comprehensively understand all the drivers, both intrinsic and extrinsic, that motivate leaders to behave in a more socially responsible manner. Analysing the intrinsic motivations only gives an initial - but incomplete - understanding the role that the complex influential motivations play in decision-making processes and behaviour

Thus comparative analysis between industrial sectors or countries might be useful to provide more knowledge on the specific drivers that induce leaders to pursue socially responsible corporate practices as a result of a variety of action logics. Such analysis could demonstrate that an identical set of action logics might well promote different and various socially responsible corporate behaviours due to differing spatial, temporal and institutional circumstances.

As it is quite difficult to capture the evolution of CSR behaviours without considering the systemic nature of the garment sector and the role it plays in relation to global competition, it is important to understand what are the systemic (extrinsic) factors that influence leaders' CSR behaviours. Such a study complements the view developed in this paper building upon the intrinsic and extrinsic motivations of local business leaders.

\section{Appendix - Summary of the Questionnaire for Structured In-depth Interviews with CSR Leaders in the Garment Sector of Bangladesh}

\section{Objective \#1: Focus on CSR Discourse (about 15 Minutes)}

After having carried out the pretest on CSR which helped to open up the atmosphere and the relation between the interviewer and interviewee, the aim of this objective is to guide the business leader to focus on CSR, its development within the garment sector and to find out its connection with CSR.

1. I would like you to reflect for a moment on your experience with the development of CSR in Bangladesh. Do you see a positive or negative trend? How do you think it will continue into the future of Bangladesh?

\section{Objective \#2: Explore the Motivation and Behaviour in Relation to CSR (about 45 Minutes)}

The main focus of the interview is on the intrinsic motivational drivers for CSR as they are perceived by the interviewee. This part of the interview is to confirm that the leader already knows a lot and understands that reality makes it difficult to punt his motivations always into practice. And it is important to ask for concrete examples of CSR behavior that can be used later on in the interview.
2. How would you define CSR? (in case it was not addressed in the CSR pre-test)

3. Which CSR activities you in your company you are more proud of? (in case it was not addressed in the CSR pre-test)

4. Which are the main limitations and opportunities to apply CSR? (in case it was not addressed in the CSR pre-test)

5. We selected you for this interview because you are recognized as a leader in the field of CSR. Are you indeed strongly motivated to be engaged in CSR? Why?

6. If we look at the Maslow's hierarchy pyramid needs, do you feel that you have achieved all its needs? Which need would it require more satisfaction?

7. Besides NEEDS, which set of values do you consider more relevant for your motivation? How do you integrate your values into your company, with your employees, clients and other society? Which is the common strongest value?

8. How would you explicit your needs, values and emotions (priority ranking):

- 'Well-being of society"

- 'protecting the environment for future generations

- $\quad$ 'taking care of employees'

- Well-being of business

- others?

9. At what point in your career did you decide to focus a lot on CSR efforts in your company? Were there specific events that lead to this decision?

10. Often, it is difficult to implement all your ambitions. Probably it is the same for CSR. Can you tell me how satisfied you are with the levels of CSR behaviour in your company/companies? What are you most proud of? What is still lacking behind in your company? (if not addressed by question 3)

11. Do you consider yourself a CSR leader?

12. In which stage of the CSR Pyramid would you position yourself?

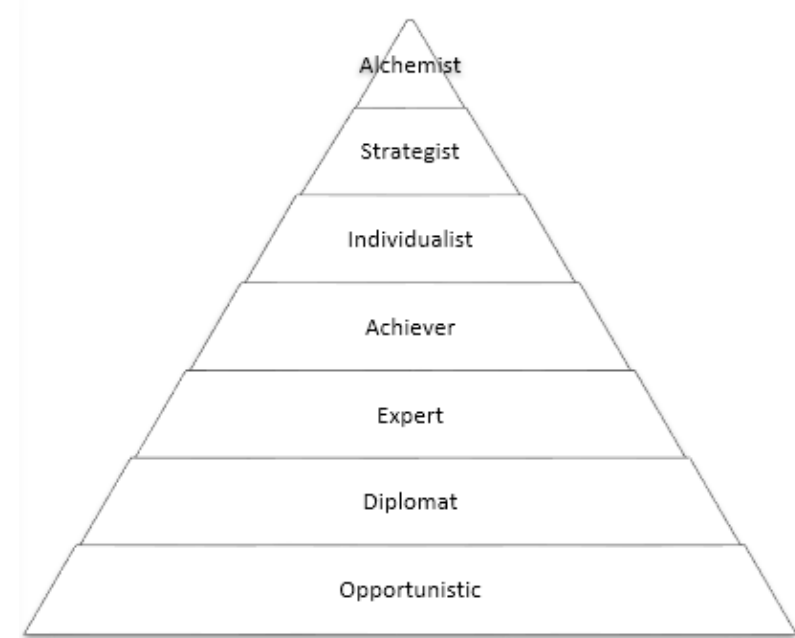


13. What characterize a CSR leader? ${ }^{2}$

Educational

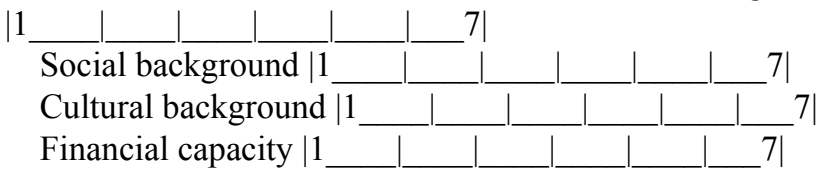

Others:

14. Who else is a CSR leader in Bangladesh? (in case it is not addressed in the CSR pre-test)

15. Which of your buyer would you consider more in line with CSR and corporate sustainability? (in case it is not addressed in the CSR pre-test)

\section{REFERENCES}

[1] Aguinis, H., \& Glavas, A. (2012). What We Know and Don't Know About Corporate Social Responsibility: A Review and Research Agenda. Journal of Management, 38, 932-968.

[2] Akora, A., Elawar, M., \& Cheng, S. (2019). Socially conscious leadership: an integrated model. Journal of leadership studies, $13(3)$.

[3] Amaeshi, K., Adegbite , E., \& Rajwani, T. (2016). Corporate Social Responsibility in Challenging and Non-enabling Institutional Contexts: Do Institutional Voids matter? Journal of Bus Ethics, 134, 135-153. DOI 10.1007/s10551-014-2420 $-4$

[4] Angus-Leppan, T., Metcalf, L., \& Benn, S. (2010). Leadership Styles and CSR Practice: An Examination of Sense making, Institutional Drivers and CSR Leadership. Journal of Business Ethics, 93, 189-213. DOI: 10.1007/s10551-009-02 21-y.

[5] Bandura, A. (1989). Social cognitive theory. In R. Vasta (Ed.), Annals of child development. 6. Six theories of child development, 1-60.

[6] Basu, K., \& Palazzo, G. (2008). Corporate social responsibility: a process model of sense making. Academy of Management Review, 33, 122-136.

[7] Benn, S., Dunphy, D., \& Perrott, B. (2011). Cases in Corporate Sustainability and Change: A Multidisciplinary Approach. Tilde University Press. ISBN: 978-0-7346-1128.

[8] Bernard, H.R., \& Ryan, G.W. (2010). Analyzing Qualitative Data. Systematic Approaches. Thousand Oaks, California: Sage Publications Inc.

[9] Boiral, O., Cayer, M., \& Baron, C. M. (2009). The action logics of environmental leadership: A developmental perspective. Journal of Business Ethics, 85, 479-499. DOI 10.1007/s10551-008-9784-2

[10] Brown, B.C. (2011). Conscious Leadership for Sustainability: A study of how leaders and change agents with post

2 Semantic scale differential. A quanti technique which allow defining the profile of CSR leaders, or companies or country. (Osgood, 1975) conventional consciousness design and engage in complex change initiatives. Ph.D. candidate, Department of Human and Organizational Systems Fielding Graduate University, Santa Barbara, California.

[11] Brown, B.C. (2014). The Future of Leadership for Conscious Capitalism. MetaIntegral Associates Report.

[12] Carey, D., Patsalos-Fox, M., \& Useem, M. (2009). Leadership lessons for hard times. A series of interviews with 14 CEOs and chairmen of major companies sheds light on the foundations of corporate leadership. McKinsey Quarterly. McKinsey Company.

[13] Christensen, L.J., Mackey, A., \& Whetten, D. (2014). Taking Responsibility for Corporate Social Responsibility: The Role of Leaders in Creating, Implementing, Sustaining, or Avoiding Socially Responsible Firm Behaviors. Academic Management Perspective, 28 (2), 164-178.

[14] Ciulla, J. B. (1999). The importance of leadership in shaping business values. Long Range Planning, 32, 166-172.

[15] Cook-Greuter, S. R. (1999). Postautonomous ego development: A study of its nature and measurement. Dissertation Abstracts International, 60 06B (UMI No. 993312).

[16] Cook-Greuter, S. R. (2004). Making the case for a developmental perspective. Industrial and Commercial Training, 36 (7), 275-281.

[17] Cook-Greuter, S. (2014). Nine Levels of Increasing Embrace In Ego Development: A Full-Spectrum Theory Of Vertical Growth And Meaning Making. Psychology.

[18] Denzin, N.K. (1978). Sociological Methods. New York: McGraw-Hill.

[19] Denzin, N.K. (2001) Interpretive Interactionism (2nd ed.). London: Sage.

[20] DiMaggio, P. J., \& Powell, W. W. (1983). The iron cage revisited: institutional isomorphism and collective rationality in organizational fields. American Sociological Review, 48 (2), 147-160.

[21] Doh, J.P. \& Quigley, N.R. (2014) Responsible Leadership and Stakeholder Management: Influence Pathways and Organizational Outcomes. The Academy of Management Perspectives, 28, 255-274. http://dx.doi.org/10.5465/amp.20 14.0013

[22] Hamel, G., \& Breen, B. (2007). The Future of Management, Harvard Business School Publishing.

[23] Hammersley, M. (2008). Troubles with triangulation. In: Bergman, Manfred Max ed. Advances in Mixed Methods Research, 22-36.

[24] Fisher, D., \& Torbert, W. R. (1991). Transforming managerial practice: Beyond the achiever stage. Research in Organizational Change and Development, 5, 143-173.

[25] Frynas, J.G., \& Yamahaki, C. (2016). Corporate social responsibility: review and roadmap of theoretical perspectives. Business Ethics an European Review, 25 (3), $258-285$.

[26] Jamali, D., \& Karam, C. (2016). Corporate Social Responsibility in Developing Countries as an Emerging Field of Study. International Journal of Management Reviews, 00, 
$1-30$.

[27] Jamali, D, Karam, C, Yin, J \& Soundararajan, V. (2017). CSR logics in developing countries: translation, adaptation and stalled development. Journal of World Business. https://doi.o $\mathrm{rg} / 10.1016 /$ j.jwb.2017.02.001.

[28] Kegan, R. (1980). Making meaning: The constructive developmental approach to persons and practice. The Personnel and Guidance Journal, 58, 373-380.

[29] Kegan, R. (1994). In over our heads: The mental demands of modern life. Cambridge, MA: Harvard University Press.

[30] King, N. (2004). Using templates in the thematic analysis of text. In: Essential Guide to Qualitative Methods in Organizational Research. Sage, London 256-270.

[31] Kohlberg, L. (1969). Stage and sequence: the cognitive developmental approach to socialization. In D. Goslin (Ed.) Handbook of Socialization Theory and research. New York: Rand McNally.

[32] Kolk, A. (2016). The social responsibility of international business: From ethics and the environment to CSR and sustainable development. Journal of World Business, 51 (1), 23-34.

[33] Fisher, D., \& Torbert, W. R. (1991). Transforming managerial practice: Beyond the achiever stage. In R. Woodman \& W. Pasmore (Eds.), Research in Organizational Change and Development (Vol. 5, pp. 143-173).

[34] Grinter, T. (2013). IndustriALL leading the struggle for Bangladeshi garment workers. IndustriALL Global worker report. www.industriall-union.org.

[35] Hemingway, C.A., \& Starkey, K. (2018). A Falling of the Veils: Turning Points and Momentous Turning Points in Leadership and the Creation of CSR. Journal of Business Ethics, 151, 875-890 https://doi.org/10.1007/s10551-017-36 59-3

[36] Lee, N., \& Lings, I. (2011). Doing business research. A guide to theory and practice. SAGE publications Ltd., London.

[37] Loevinger, J. (1976). Ego development: conceptions and theories. San Francisco: Jossey-Bass.

[38] Maak, T., \& Pless, N. M. (2006). Responsible Leadership in a Stakeholder Society - A Relational Perspective. Journal of Business Ethics, 66, 99-115.

[39] Maon, F., Lindgreen, A., \& Swaen, V. (2010). Organizational stages and cultural phases: A critical review and a consolidative model of corporate social responsibility development. International Journal of Management Reviews, 12 (1), 20-38.

[40] Marrewijk, M. V., \& Were, M. (2003). Multiple Levels of Corporate Sustainability. Journal of Business Ethics, 44 (2/3), 107-119.

[41] McCauley, C. D., Drath, W. H., Palus, C. J., O'Connor, P. M. G., \& Baker, B. A. (2006). The use of constructive developmental theory to advance the understanding of leadership. The Leadership Quarterly, 17 (6), 634-653. Doi: 10.1016/j.leaqua.2006.10.006.

[42] Nijhof, A.H.J., \& Jeurissen, R.J.M. (2010). The glass ceiling of corporate social responsibility: Consequences of a business case approach towards CSR. International Journal of Sociology and Social Policy, 30 (11/12), 618-631.

[43] Paine, L.S. (1994). Managing for Organizational Integrity. Harvard Business Review, March-April 1994.

[44] Piaget, J. (1954). The construction of reality in a child. New York: Basic Books.

[45] Pisani, N., Kourula, A., Kolk, A., \& Meijer, R. (2017). How global is international CSR research? Insights and recommendations from a systematic review. Journal of World Business, 52(5), 591-614. https://doi.org/10.1016/j.jw b.2017.05.003.

[46] Reimann, F., Rauer, J., \& Kaufmann, L. (2015). MNE Subsidiaries' Strategic Commitment to CSR in Emerging Economies: The Role of Administrative Distance, Subsidiary Size, and Experience in the Host Country. Journal of Business Ethics, 132, 845-857. DOI10.1007/s105 51-014-2334-1.

[47] Rooke, D., \& Torbert, W. R. (1998). Organizational transformation as a function of CEO's developmental stage. Organization Development Journal, 16 (1), 11-28.

[48] Rooke, D., \& Torbert, W.R. (2005). Seven Transformations of Leadership. Harvard Business Review.

[49] Senge, P.M. (2008). The Necessary Revolution: How Individuals and Organizations Are Working Together to Create a Sustainable World. Doubleday.

[50] Shafique, I., \& Beh, L-S. (2017). Shifting Organizational Leadership Perspectives: An Overview of Leadership Theories. International Journal of Economic Perspectives, 11 (4), 134-143.

[51] Shi, Y., \& Ye, M.L. (2016). Responsible Leadership: Review and Prospects. American Journal of Industrial and Business Management, 6, 877-884. http://dx.doi.org/10.4236/ajibm.20 16.68083

[52] Spano, S. L. (2015). Constructive-Developmental Theory and the Integrated Domains of Wisdom: Are Post-Conventional Leaders Really Wiser? Integral Review, 11 (2).

[53] Stahl, G.K. and de Luque, M.S. (2014). Antecedents of Responsible Leader Behavior: A Research Synthesis, Conceptual Framework, and Agenda for Future Research. The Academy of Management Perspectives, 28, 235-254. http://dx.doi.org/10.5465/amp.2013.0126

[54] Su, W., Peng, M.W., Tan, W., \& Cheung, Y-L. (2016). The Signaling Effect of Corporate Social Responsibility in Emerging Economies. Journal of Business Ethics, 134, 479491. DOI 10.1007/s10551-014-2404-4.

[55] Tideman, S., \& Arts, M., (2013). Empowered Leadership Mind-sets and Qualities to Create Post-crisis Economical, Societal and Ecological Value. Chapter 32 in Gorillas, Markets and the Search for Economic Value, 317-326.

[56] Torbert, W. (1987). Managing the Corporate Dream: Restructuring for Long-term Success. Homewood, IL: Dow Jones-Irwin

[57] Torbert, B., \& Associates (2004). Action Inquiry: The Secret of Timely and Transforming Leadership, San Francisco, CA: Berrett-Koehler Publishers, Inc. 
[58] Tourigny, L., Han, J., Baba, V. V., \& Pan, P. (2019). Ethical Leadership and Corporate Social Responsibility in China: A Multilevel Study of Their Effects on Trust and Organizational Citizenship Behavior. Journal of Business Ethics, 158 (2), 427-440. DOI: 10.1007/s10551-017-3745-6.

[59] Trevino, L.K., Brown, M., \& Hartman, L.P. (2003). A qualitative investigation of perceived executive ethical leadership: Perceptions from inside and outside the executive suite. Human Relations, 55, 5-37.

[60] US Department of Labor, (2013). News Statements: Statement by the US Government on Labor Rights and Factory Safety in Bangladesh. For Immediate Release July 19, 2013. Office of Public Affairs Contact: Gloria Della. Washington, D.C. Phone: 292-693-4679. Release Number: 13-1494-NAT. http://social.dol.gov

[61] Visser, W. (2011). The Nature of CSR leadership. CSR International Paper Series, 4.

[62] Waldman, D. A., Siegel, D. S., \& Javidan, M. (2006). Components of CEO transformational leadership and corporate social responsibility. The Journal of Management Studies, 43 (8), 1703.

[63] Weaver, G. R., Trevino, L. K., \& Cochran, P. L. (1999). Integrated and decoupled corporate social performance: Management commitments, external pressure, and corporate ethics practices. Academy of Management Journal, 42,539552.

[64] Wilber, K. (2000). A theory of everything: An integral vision for business, politics, science, and spirituality. Boston: Shambhala.

[65] Woszczyna, K., Dacko-Pikiewicz, Z., \& Lis, M. (2015). Responsible leadership: a real need or transient curiosity. 20th International Scientific Conference Economics and Management - 2015 (ICEM-2015). Procedia - Social and Behavioral Sciences, 213, $546-551$.

[66] Zadek, S. (2004). The path to corporate responsibility. Harvard Business Review, 82, 125-132.

[67] Zheng, Q., Luo, Y., \& Maksimov, V. (2015). Achieving legitimacy through corporate social responsibility: The case of emerging economy firms. Journal of World Business, 50, 389-403. 